\title{
PERLINDUNGAN HUKUM TERHADAP PEMILIK TANAH SERTIFIKAT HAK MILIK ATAS GUGATAN ORANG LAIN
}

\section{LEGAL PROTECTION OF LAND OWNERSHIP CERTIFICATE OF RIGHTS FOR OTHERS}

\author{
Ide Prima Hadiyanto ${ }^{1 *)}$ Fika Anggraini ${ }^{2}$ ) \\ ${ }^{1,2}$ Fakultas Hukum Universitas Abdurachman Saleh Situbondo \\ ${ }^{1}$ Email : ide_prima_hadiyanto@unars.ac.id
}

\begin{abstract}
ABSTRAK
Dalam masyarakat, perolehan hak atas tanah lebih sering dilakukan dengan peralihan hak, yaitu dengan melalui jual beli. Syarat-syarat materiil jual beli sangat menentukan akan sahnya jual beli tanah tersebut. Jika salah satu syarat materiil ini tidak dapat dipenuhi, atau dikatakan penjual bukan merupakan orang yang berhak atas tanah yang dijualnya atau pembeli tidak memenuhi syarat menjadi pemilik hak atas tanah menurut Undangundang atau tanah yang diperjualbelikan sedang dalam sengketa atau merupakan tanah yang tidak boleh diperjualbelikan, maka jual beli tanah tersebut adalah tidak sah. Sertifikat merupakan surat tanda hak yang kuat akan tetapi sertifikat bukan satu-satunya surat tanda bukti pemegang hak atas tanah namun masih ada bukti lain tentang kepemilikan yang mampu membuktikan ketidakabsahan sertifikat tanah tersebut. Dalam hal sertifkat hak atas tanah yang diterbitkan oleh Kantor Pertanahan Kabupaten/Kota telah berusia 5 (lima) tahun tidak berarti hak menggugatnya hilang bagi orang yang merasa dirugikan atas diterbitkannya sertifikat hak atas tanah tersebut. Semua tanah yang termasuk tanah yang telah dilekatkan hak dapat dimohonkan pembatalan apabila terdapat putusan Pengadilan yang telah berkekuatan hukum tetap maupun adanya cacat hukum administrasi.
\end{abstract}

Kata Kunci: Tanah, Sertifikat Hak Milik, Gugatan

\section{ABSTRACT}

In the community, the acquisition of land rights is more often done by the transfer of rights, namely through sale and purchase. Material conditions of sale and purchase will determine the validity of the sale and purchase of the land. If any of these material conditions cannot be fulfilled, or it is said that the seller is not the person entitled to the land he is selling or the buyer is not eligible to be the owner of the land rights according to the Law or the land being traded is in dispute or is land that may not be traded, then buying and selling land is not legal. The certificate is a strong certificate of ownership but the certificate is not the only proof of the holder of land rights but there is still other evidence of ownership that can prove the invalidity of the land certificate. In the case of a land rights certificate issued by a District / City Land Office that is 5 (five) years old, it does not mean that the right to sue is lost for people who feel disadvantaged over the issuance of the land rights certificate. All land, including land that has been attached with rights, can be requested for cancellation if there is a court decision that has permanent legal force or if there is an administrative legal flaw. 
P-ISSN 2580 - 7781

E-ISSN $2615-3238$

Keywords: Land, Title Certificate, Lawsuit

\section{PENDAHULUAN}

Seiring dengan bertambahnya manusia dari tahun ke tahun, sedangkan jumlah luas tanah yang dapat dikuasai manusia terbatas sekali, maka tanah menjadi masalah yang sangat krusial bagi manusia. Dalam kehidupan sehari-hari, tanah seringkali menjadi persengketaan, bahkan sampai sidang ke Pengadilan. Hal ini timbul karena tanah memiliki fungsi dan arti yang sangat penting bagi kehidupan masyarakat, membuat masyarakat berusaha untuk memperoleh tanah dengan berbagai cara, bahkan dengan menyerobot tanah milik orang lain.

Persengketaan tanah, dapat menimbulkan konflik-konflik yang berkepanjangan antar warga masyarakat yang bersengketa. Untuk mencegah meluasnya masalah sengketa tanah tersebut, maka pemerintah mengadakan pendaftaran tanah yang nantinya akan menghasilkan sertifikat tanah. Adanya sertifikat tanah yang diterbitkan merupakan bukti kepemilikan terhadap suatu bidang tanah, disini pemegang sertifikat hak atas tanah telah mendapat perlindungan hukum dan dijamin oleh undang-undang atas tanah yang dimilikinya. Artinya, apabila terjadi sengketa tanah dimana dengan adanya sertifikat yang dimiliki oleh pemegang sertifikat maka kedudukan hukum pemegang sertifikat adalah kuat dan hakim berkewajiban untuk mempertimbangkan alat bukti sertifikat sebagai alat bukti yang sah dan kuat di samping mempertimbangkan alat-alat bukti yang lain.

Beberapa permasalahan mengenai sertifikat tanah yang muncul dalam masyarakat, antara lain prosedur perolehannya yang rumit, lama dan membutuhkan biaya yang banyak, sehingga membuat masyarakat enggan mendaftarkan tanahnya. Selain itu, ada juga sertifikat yang cacat hukum seperti adanya kesalahan prosedur, kesalahan subyek hak, kesalahan obyek hak, kesalahan dalam penerapan peraturan perundang-undangan, kesalahan jenis hak, tumpang tindih hak, kesalahan perhitungan luas, kesalahan data fisik dan data yuridis. Jika terjadi hal demikian, tentu bertentangan dengan maksud dan tujuan pendaftaran tanah yaitu memberikan kepastian hukum bagi pemegang hak tersebut. Untuk menanggulangi timbulnya sertifikat hak atas tanah yang 
P-ISSN 2580 - 7781

E-ISSN $2615-3238$

mengandung cacat hukum administrative, diperlukan adanya upaya aktif dan peran serta dari seluruh lapisan masyarakat baik instansi pemerintah maupun warga masyarakat itu sendiri serta instansi yang terkait dengan bidang pertanahan seperti Notaris/Pejabat Pembuat Akta Tanah (PPAT), serta peranan lembaga penegak hukum atau badan peradilan.

Berdasarkan uraian tersebut diatas muncul permasalahan yang akan diteliti adalah sebagai berikut:

1. Apa akibat hukum praktik jual beli tanah yang masih dalam proses sengketa?

2. Bagaimana perlindungan hukum terhadap pemilik tanah Sertifikat Hak Milik atas gugatan orang lain?

\section{METODE PENELITIAN}

Dalam rangka tindak lanjut perolehan data sebagaimana yang diharapkan, maka penulis menetapkan teknik pengumpulan data Sekunder yaitu dengan cara Menganilisa langsung perkara-perkara yang terkait penulisan tersebut di Pengadilan Negeri dan Pengadilan Agama serta Badan Pertanahan Nasional, sedangkan untuk data sekunder, teknik pengumpulan data dilakukan dengan cara membaca, menelaah secara seksama buku-buku, dokumen-dokumen dan lain-lain. Jenis data yang akan digunakan dalam penelitian ini adalah:

\section{Data Primer}

Yaitu keterangan atau fakta yang diperoleh secara langsung dari sumber data atau melalui penelitian di lapangan dalam hal ini data yang diperoleh dari Pengadilan Negeri dan Pengadilan Agama serta Badan Pertanahan Nasional.

\section{Data Sekunder}

Yaitu data yang diperoleh secara tidak langsung melalui penelitian Kepustakaan dan teknik pengumpulan dan inventarisasi buku-buku, karya ilmiah, artikel-artikel dan juga dari internet, serta data yang diperoleh dari instansi atau lembaga tempat penelitian penulis yang telah tersedia. 
P-ISSN 2580 - 7781

E-ISSN $2615-3238$

\section{A. Sumber Data}

1. Sumber Data Primer

Sejumlah data atau fakta yang diambil secara langsung dari sumber data di lapangan (Pengadilan Negeri dan Pengadilan Agama serta Badan Pertanahan Nasional).

\section{Sumber Data Sekunder}

Semua data sekunder yang bersifat menjelaskan bahan hukum primer berupa pendapat para ahli sarjana serta literatur-literatur yang relevan dengan objek penelitian.

Bahan-bahan hukum yang digunakan dalam penelitian ini antara lain:

\section{a. Bahan Hukum Primer}

Yaitu bahan hukum yang mengikat yang terdiri dari peraturan perundangundangan yang berlaku atau ketentuan-ketentuan yang berlaku.

b. Bahan Hukum Sekunder

Bahan hukum sekunder yang digunakan untuk mendukung bahan hukum primer, diantaranya yang berasal dari karya para sarjana, jurnal, data yang diperoleh dari instansi, serta buku-buku kepustakaan yang dapat dijadikan referensi yang dapat menunjang penelitian ini.

c. Bahan Hukum Tersier

Yaitu bahan hukum yang mengandung bahan hukum sekunder yang berasal dari amus. Data-data yang terkumpul baik data primer dan sekunder selanjutnya diolah dan dianalisa dengan menggunakan analisis kualitatif yaitu dengan menjelaskan apa yang menjadi isu dalam penelitian ini kemudian mendeskripsikannya dan juga menganalisa secara Kualitatif yaitu metode penelitian yang menekankan pada aspek suatu pemahaman secara mendalam terhadap suatu masalah. 
P-ISSN 2580 - 7781

E-ISSN $2615-3238$

\section{HASIL PENELITIAN DAN PEMBAHASAN}

\section{Pengertian Tanah dan Dasar Hukum Tanah}

Istilah tanah (agraria) berasal dari beberapa bahasa, dimana istilah agraria berasal dari kata Akker (Bahasa Belanda), Agros (Bahasa Yunani) berarti tanah pertanian, Agger (Bahasa Latin) berarti tanah atau sebidang tanah, Agrarius (Bahasa Latin) berarti perladangan, persawahan, pertanian, Agrarian (Bahasa Inggris) berarti tanah untuk pertanian.

Sumber hukum tanah nasional menurut Boedi Harsono dibagi menjadi dua macam, yaitu :

1. Sumber hukum tertulis :

a. Undang-Undang Dasar Negara Republik Indonesia Tahun 1945 Pasal 33 ayat (3).

b. Ketetapan MPR IX/MPR/2001 tentang Pembaruan Agraria Dan Pengelolaan Sumber Daya Alam.

c. Undang-Undang Nomor 5 Tahun 1960 Tentang Peraturan Dasar PokokPokok Agraria (UUPA).

d. Peraturan Pelaksana dari Undang-Undang Pokok Agraria.

e. Peraturan-peraturan yang bukan Peraturan Pelaksana dari Undang-Undang Pokok Agraria yang dikeluarkan setelah tanggal 24 September 1960 karena suatu masalah perlu diatur (seperti : Undang-Undang Nomor 51/Prp/1960 tentang Larangan Pemakaian Tanah Tanpa Izin yang Berhak atau Kuasanya, LN 1960-158, TLN 2160.

f. Peraturan-peraturan lama yang untuk sementara masih berlaku berdasarkan ketentuan pasal-pasal peralihan yang merupakan bagian hukum tanah yang positif, bukan bagian hukum tanah nasional.

2. Sumber hukum tidak tertulis, yaitu :

a. Norma-norma hukum adat yang sudah di-saneer menurut ketentuan Pasal 5, Pasal 56 dan Pasal 58 Undang-Undang Pokok Agraria.

b. Hukum kebiasaan baru, termasuk yurisprudensi dan praktik administrasi yang berkaitan dengan tanah. 
Selain sumber hukum di atas, yang dapat menjadi sumber hukum tanah nasional adalah perjanjian yang diadakan oleh para pihak berdasarkan pengaturan Pasal 1338 Kitab Undang-Undnag Hukum Perdata. Akan tetapi terdapat pembatasan dari ketentuan pasal tersebut, khususnya di bidang hukum tanah selama perjanjian tersebut tidak melanggar atau tidak bertentangan dengan sebagaimana yang diatur dalam Undang-Undang Pokok Agraria.

\section{Hak-hak Penguasaan Atas Tanah}

Hak atas tanah adalah hak yang memberi wewenang kepada pemegang haknya untuk menggunakan atau mengambil manfaat dari tanah yang di hakinya. Hak atas tanah dibedakan menjadi dua kelompok, yaitu:

1. Hak atas tanah yang bersifat primer

Merupakan hak yang langsung diberikan oleh negara kepada pemegang haknya, hak ini meliputi:
a. Hak Milik,
b. Hak Guna Bangunan,
c. Hak Guna Usaha,
d. Hak Pakai.

2. Hak atas tanah yang bersifat sekunder

Adalah hak atas tanah yang berasal dari tanah pihak lain. Macam-macam hak atas tanah yang bersifat sementara, adalah Hak Gadai (Gadai Tanah), Hak Usaha Bagi Hasil (Perjanjian Bagi Hasil), Hak Menumpang, dan Hak Sewa Tanah Pertanian.

\section{Pengertian Jual Beli Tanah}

Dari pengertian Pasal 1457 kitab Undang-undang Hukum Perdata yang disebut dengan jual beli tanah adalah suatu perjanjian pihak yang memiliki tanah, yang disebut penjual, berjanji dan mengikatkan diri untuk menyerahkan haknya atas tanah yang bersangkutan kepada pihak lain yang disebut pembeli. Sedang pihak pembeli berjanji atau mengikatkan diri untuk membayar harga yang sudah disetujui, yang dijual belikan menurut hukum barat ini apa yang disebut tanahtanah hak barat yaitu tanah-tanah hak Eigendom, Erfpacht, Opstal. 


\section{P-ISSN $2580-7781$}

E-ISSN $2615-3238$

Jual beli tanah menurut hukum adat yaitu suatu perbuatan pemindahan atas tanah yang bersifat terang dan tunai. Terang yang berarti bahwa perbuatan pemindahan hak tersebut harus dilakukan di hadapan pejabat yang berwenang dan disaksikan oleh beberapa orang saksi. Sedangkan bersifat tunai maksudnya ialah perbuatan pemindahan hak dan pembayaran harganya dilakukan secara serentak. Pembeli dianggap telah membayar harga tanah secara kontan atau tunai walaupun baru dibayar sebagian dan sisa pembayaran harga tanah tersebut dianggap sebagai hutang piutang.

\section{Pengertian Akta}

Pengertian Akta Dalam Undang-Undang Nomor 2 Tahun 2014 tentang Jabatan Notaris menyebutkan bahwa akta notaris yang selanjutnya disebut Akta adalah akta autentik yang dibuat oleh atau di hadapan Notaris menurut bentuk dan tata cara yang ditetapkan dalam Undang-Undang ini. Hal ini tercantum dalam Pasal 1 angka 7 Undang-Undang Nomor 2 Tahun 2014 tentang Jabatan Notaris.

\section{Peralihan Hak Atas Tanah Melalui Jual Beli}

Peralihan hak atas tanah adalah perbuatan hukum pemindahan hak atas tanah yang dilakukan dengan sengaja agar hak tersebut terlepas dari pemegangnya semula dan menjadi pihak lain. Dalam masyarakat, perolehan hak atas tanah, sering dilakukan dengan cara peralihan hak, yaitu melalui jual beli.

Syarat-syarat jual beli tanah ada 2 (dua) yaitu:

1. Syarat Materiil

Syarat-syarat materiil sangat menentukan akan sahnya jual beli tanah tersebut, antara lain sebagai berikut : Penjual, Pembeli dan Tanah yang bersangkutan boleh diperjual belikan atau tidak dalam sengketa.

2. Syarat Formil.

Setelah semua persyaratan materiil terpenuhi, PPAT akan membuat akta.

a. Pembuatan akta tersebut harus dihadiri oleh pihak yang melakukan jual beli atau kuasa dari penjual, pembeli dan disaksikan oleh 2 (dua) orang saksi yang memenuhi syarat untuk bertindak sebagai saksi.

b. Akta dibuat dalam bentuk asli dalam 2 (dua) lembar yaitu lembar pertama 


\section{P-ISSN 2580 - 7781}

E-ISSN $2615-3238$

sebanyak 1 (satu) rangkap disimpan oleh PPAT yang bersangkutan dan lembar kedua sebanyak 1 (satu) rangkap disampaikan kepada kantor pertanahan untuk keperluan pendaftaran dan kepada pihak-pihak yang berkepentingan dapat diberikan salinannya.

c. Setelah akta tersebut dibuat, selambat-lambatnya 7 (tujuh) hari kerja sejak tanggal ditandatanganinya akta yang bersangkutan, PPAT wajib menyampaikan akta yang dibuatnya berikut dokumen-dokumen yang bersangkutan kepada Kantor Pertanahan untuk didaftarkan dan PPAT wajib menyampaikan pemberitahuan tertulis mengenai telah disampaikannya akta tersebut kepada para pihak yang bersangkutan.

\section{KESIMPULAN}

Dalam proses jual beli harus terpenuhi syarat-syarat materiil dan syaratsyarat formil. Syarat-syarat materiil yaitu : penjual adalah orang yang berhak atas tanah yang akan dijualnya, pembeli adalah orang yang berhak untuk mempunyai hak atas tanah yang dibelinya dan tanah yang bersangkutan boleh diperjual belikan atau tidak dalam sengketa. Syarat Formil jual beli adalah jual beli tersebut harus didaftarkan pada PPAT. Syarat-syarat materiil inilah yang sangat menentukan akan sahnya jual beli tanah tersebut. Jika salah satu syarat materiil dalam jual beli tidak dapat dipenuhi, atau dikatakan penjual bukan merupakan orang yang berhak atas tanah yang dijualnya atau pembeli tidak memenuhi syarat menjadi pemilik hak atas tanah menurut Undang-undang atau tanah yang diperjualbelikan sedang dalam sengketa atau merupakan tanah yang tidak boleh diperjualbelikan, maka jual beli tanah tersebut adalah tidak sah.

Kepemilikan sertifikat hak milik atas tanah tidak memiliki perlindungan hukum serta jaminan kepastian hukum yang diberikan negara setelah dilakukan proses pendaftaran tanah dan munculnya sertifikat hak milik atas tanah. Hal ini sesuai dengan ketentuan dalam pasal 32 Ayat (2) Peraturan Pemerintah No.24 Tahun 1997 ini bertujuan memberikan kepastian hukum kepada 2 (dua) pihak, yaitu: 
a. Bagi pemilik sertifikat, kalau sudah lewat 5 (lima) tahun sejak diterbitkan sertifikat oleh Kantor Pertanahan Kabupaten/Kodya tidak ada yang mengajukan gugatan, maka ia terbebas dari gangguan pihak lain yang merasa sebagai pemilik tanah tersebut.

b. Bagi pemilik tanah yang sebenarnya, ia wajib menguasai tanah secara nyata dan mendaftarkan tanahnya ke Kantor Pertanahan Kabupaten/Kota setempat agar terhindar dari kemungkinan tanahnya didaftarkan atas nama orang lain.

\section{DAFTAR PUSTAKA}

\section{A. Buku}

Abdurrahman, Soejono. 1998, Prosedur Pendaftaran Tanah Hak Milik, Hak Sewa Bangunan, Hak Guna Bangunan, JakartaL Rineka Cipta.

Edy Ruchyat, 2007, Politik Pertanahan Nasional Sampai orde Reformasi, Alumni, Bandung.

Effendie, Bachtiar. 1993, Pendaftaran Tanah di Indonesia dan Peraturan Pelaksanaannya, Bandung,: Alumni,

Hadikusuma, Hilman. 1993, Hukum Waris Adat, Cipta Aditya Bhakti Bandung

Harsono, Boedi. 2005, Hukum Agraria Indonesia, Sejarah Pembentukan UUPA, Isi dan Pelaksanaannya, Jakarta : Djambatan.

Harsono, Boedi. Hukum Agraria Indonesia (Himpunan Peraturan-peraturan Tanah). cet.15. Jakarta : Djambatan, 2002.

Harsono, Boedi. Sejarah Pembentukan Undang-undang Pokok Agraria, Isi dan Pelaksanaannya), cet.9. Jakarta : Djambatan, 2002.

Harsono, Boedi. Menuju Penyempurnaan Hukum Tanah Nasional (Dalam Hubungannya dengan Tap MPR RI IX/MPR/2001. cet.1. Jakarta: Universitas Trisakti, 2002.

Moleong, Lexy J. 2007. Metodologi Penelitian Kualitatif. Bandung: Remaja Rosdakarya.

Muhammad, Abdulkadir. 1990, Hukum Waris., Remaja Rosda Karya, Bandung,

Parlindungan, AP. 1988, Pendaftaran Tanah Tanah dan Konfersi hak milik atas tanah menurut UUPA, Bandung: Alumni.

Perangin, Effendi. 1994, Hukum Agraria di Indonesia, Jakarta: PT. Raja Grafindo Persada.

Prawirohamidjojo,R. Soetojo. 2005, Hukum Waris Kodifikasi, Surabaya: Airlangga University Press.

Saleh, K. Wantjik. 1995, Hak Anda Atas Tanah, Jakarta: Ghalia Indonesia

Soedjenro, Kartini. Perjanjian Peralihan Hak Atas Tanah Yang Berpotensi Konflik. cet.1. Yogyakarta: Konisius, 2001.

Soekanto, Soejono. 1981. Pokok-pokok Hukum Adat, Bandung: Alumni

Soemitro, Ronny Hanitjo. 1990, Metodologi Penelitian Hukum dan Jurimentri, Ghalia Indonesia, Jakarta. 
Soerjopratiknjo, Hartono. 1992, Hukum Waris tanpa Wasiat, Andi Offset, Yogyakarta.

Suardi. 2005, Hukum Agraria, Jakarta, Badan Penertbit IBLM.

Sutedi, Adrian. 2006, Peralihan Hak Atas Tanah dan Pendaftarannya, Jakarta : Sinar Grafika.

Tutik, Titik Triwulan. 2006. Pengantar Hukum Perdata di Indonesia. Jakarta :PT. Prestasi Pustaka.

Urip Santoso, Pendaftaran dan Peralihan Hak atas Tanah, Jakarta: Kencana, 2010.

Waluyo, Bambang. 1991, Penelitian Hukum Dalam Praktek, Sinar Grafika, Jakarta.

Wargakusumah, Hasan. 1995, Hukum Agraria I, Jakarta: PT. Gramedia Pustaka Utama.

\section{B. Peraturan Perundang-undangan}

Undang-Undang Dasar 1945.

Undang-Undang Nomor 5 Tahun 1960 Tentang Undang-Undang Pokok Agraria.

Peraturan Pemerintah Nomor 10 Tahun 1961 Tentang Pendaftaran Tanah.

Peraturan Pemerintah Nomor 24 Tahun 1997 Tentang Pendaftaran Tanah.

PP No. 37 Tahun 1998 Tentang Peraturan Pemerintah Tentang Peraturan Jabatan Pejabat Pembuat Akta Tanah.

Peraturan Menteri Agraria/Kepala BPN Nomor 3 Tahun 1997 tentang Ketentuan Pelaksana PP 24/1997 Tentang Pendaftaran Tanah.

Peraturan Menteri Agraria/Kepala BPN Nomor 4 Tahun 1999 tentang Peraturan Jabatan Pejabat Pembuat Akta Tanah. 